\title{
Hydrogen sulfide exhibits cardioprotective effects by decreasing endoplasmic reticulum stress in a diabetic cardiomyopathy rat model
}

\author{
FANG LI*, JIAN LUO*, ZHIXIONG WU, TING XIAO, OU ZENG, LIN LI, YAN LI and JUN YANG \\ Department of Cardiology, The First Affiliated Hospital of University of South China, Hengyang, Hunan 421001, P.R. China
}

Received March 13, 2015; Accepted March 7, 2016

DOI: $10.3892 / \mathrm{mmr} .2016 .5289$

\begin{abstract}
Endoplasmic reticulum (ER) stress is critical in the occurrence and development of diabetic cardiomyopathy (DC). Hydrogen sulfide $\left(\mathrm{H}_{2} \mathrm{~S}\right)$ has been found to be the third gaseous signaling molecule with anti-ER stress effects. Previous studies have shown that $\mathrm{H}_{2} \mathrm{~S}$ acts as a potent inhibitor of fibrosis in the heart of diabetic rats. This study aimed to demonstrate whether $\mathrm{H}_{2} \mathrm{~S}$ exhibits protective effects on the myocardium of streptozotocin (STZ)-induced diabetic rats by suppressing ER stress. In this study, diabetic models were established by intraperitoneal (i.p.) injection of $40 \mathrm{mg} / \mathrm{kg}$ STZ. The STZ-treated mice were divided into three groups, and subsequently treated with normal saline, $30 \mu \mathrm{mol} / \mathrm{kg}$ or $100 \mu \mathrm{mol} / \mathrm{kg} \mathrm{NaHS}$, i.p., respectively, for 8 weeks. The extent of myocyte hypertrophy was measured using hematoxylin and eosin-stained sections and collagen components were investigated using immunostaining. The expression of glucose-regulated protein (Grp78), C/EBP-homologous protein (CHOP) and caspase-12 in the heart tissue of each group was detected by western blot analysis. It was demonstrated that $\mathrm{H}_{2} \mathrm{~S}$ could improve myocardial hypertrophy and myocardial collagen deposition in diabetic rats. In addition, it could reduce the expression of Grp78, caspase-12 and CHOP. In conclusion, these findings demonstrate that $\mathrm{H}_{2} \mathrm{~S}$ suppresses STZ-induced ER stress in the hearts of rats, and it may serve as a novel cardioprotective agent for DC.
\end{abstract}

Correspondence to: Professor Jun Yang, Department of Cardiology, The First Affiliated Hospital of University of South China, 69 Chuanshan Road, Shigu, Hengyang, Hunan 421001, P.R. China

E-mail: yangjunincn@163.com

*Contributed equally

Key words: hydrogen sulfide, diabetic cardiomyopathy, endoplasmic reticulum stress, apoptosis

\section{Introduction}

In diabetic patients, a wide range of structural reconfiguration has been observed, such as cardiomyocyte hypertrophy, ventricular dilation, prominent interstitial fibrosis $(1,2)$, diastolic and systolic dysfunction, and left ventricular hypertrophy $(3,4)$. This disease process is termed diabetic cardiomyopathy (DC), which is a heart muscle-specific disease without other vascular pathology $(5,6)$. Investigation revealed that patients with diabetes mellitus (DM) were more likely to suffer from coronary artery disease, hypertension and mortality following myocardial infarction $(7,8)$, while DC was one of the most common serious cardiovascular complications of DM (9). Cellular metabolic abnormalities and defections of organelles were shown to participate in the pathology of DC (10-14), which is a chronic and complex process associated with impaired calcium homeostasis, increased lipid uptake, myocardial insulin resistance, glucotoxicity, increased oxidative stress and activation of the renin-angiotensin system (15). Furthermore, the pathological role of endoplasmic reticulum (ER) stress in DC has been noted in a number of studies (16-18).

The endoplasmic reticulum (ER) is central in lipid synthesis, calcium homeostasis, and the folding and maturation of membrane and secretory proteins (19). The normal functions of the ER can be disturbed by various conditions, such as glucotoxicity, $\mathrm{ER}^{-\mathrm{Ca}^{2+}}$ disequilibrium, ischemia and hypoxia, free radicals, hyperhomocysteine, increased protein synthesis and gene mutation, which results in ER stress (ERS) (20-25). ERS occurs in a number of pathological conditions, such as diabetic kidney disease (26). ERS is known to be involved in a number of complex homeostatic signaling pathways among which the unfolded protein response (UPR) is most commonly recognized (27). The expression of glucose-regulated protein 78 (Grp78) can be activated by the UPR, which is known to be a safeguard for normal function of the ER. Grp78 is an ER resident protein, which reacts to accumulated proteins. Moderate ER stress can relieve injury triggered by stress, while severe and chronic ERS result in apoptosis and induce a number of diseases. Apoptotic processes can be initiated by caspase-12-dependent pathways and CHOP-dependent pathways $(28,29)$, which are ER-specific pathways. Recently, a number of studies have demonstrated the crucial role of ER stress in the development of DC $(30,31)$. Therefore, it was 
hypothesized that downregulating ER stress in diabetic rats could prevent the development of DC.

Hydrogen sulfide $\left(\mathrm{H}_{2} \mathrm{~S}\right)$ is a toxic gas with a pungent rotten egg smell. It is produced naturally in mammalian tissues and exhibits various biological and physiological effects (32-35). A large number of experiments showed that $\mathrm{H}_{2} \mathrm{~S}$ had the anti-ER stress, anti-apoptosis, anti-inflammatory and anti-oxidant effects (36-39). In the nervous system, $\mathrm{H}_{2} \mathrm{~S}$ acts as a neuroprotectant and may exhibit pharmacological effects in patients with Parkinson's disease and Alzheimer's disease (40-45). A recent study found that $\mathrm{H}_{2} \mathrm{~S}$ had antidepressant-like and anxiolytic-like effects (46). In the cardiovascular system, $\mathrm{H}_{2} \mathrm{~S}$ was shown to relax smooth muscles, regulate blood pressure (47-49) and prevent atherosclerosis $(39,50-52)$, which resulted in the prevention of ischemia-reperfusion injury in myocardial cells (53-55). In $\mathrm{DM}, \mathrm{H}_{2} \mathrm{~S}$ has been shown to improve insulin resistance and protect $\beta$-cells in the pancreas $(56,57)$. A previous study has also shown that $\mathrm{H}_{2} \mathrm{~S}$ acts as a potent inhibitor of fibrosis in the heart of diabetic rats (58). Thus, these studies suggested that $\mathrm{H}_{2} \mathrm{~S}$ may exhibit a cardioprotective effect in the pathophysiology of DC. However, whether $\mathrm{H}_{2} \mathrm{~S}$ can prevent the pathological process of DC by suppressing ERS has not yet been demonstrated. Thus, the present study aimed to demonstrate whether $\mathrm{H}_{2} \mathrm{~S}$ exhibits protective effects on the myocardium of streptozotocin (STZ)-induced diabetic rats by suppressing ERS.

\section{Materials and methods}

Animals. Fifty adult male Sprague-Dawley (SD) rats, weighing 280-300 g, were purchased from the SJA Lab Animal Center of Changsha (Changsha, China). The animals were maintained in accordance with institutional policies, and all experiments were performed with approval of the University of China Committee on the Use and Care of Animals of University of South China (Hengyang, China).

Drugs and reagents. Sodium hydrosulfide (NaHS) was purchased from Sigma-Aldrich (St. Louis, MO, USA). Streptozotocin (STZ) was purchased from MP Biomedicals Company (Santa Ana, CA, USA). Specific monoclonal anti-GRP78 antibody was purchased from Epitomics Inc. (Burlingame, UK). Specific monoclonal anti-CHOP antibodies were purchased from Proteintech Group, Inc. (Chicago, IL, USA). Specific monoclonal anti-caspase-12 antibodies were obtained from Sigma-Aldrich. Anti-rabbit and anti-rat IgG secondary antibodies were purchased from Proteintech Group, Inc. Cell lysis buffer for western blot analysis, Enhanced Chemiluminescence Reagent kit, Bicinchoninic acid assay (BCA) Protein Assay kit and sodium dodecyl sulfate-polyacrylamide gel electrophoresis (SDS-PAGE) Gel Preparation kit were purchased from Beyotime Institute of Biotechnology (Shanghai, China).

Study design. Prior to the experiment, rats were adapted to the experimental environment for one week. During this period, $\mathrm{SD}$ rats were kept under a $12 \mathrm{~h}$ light/dark cycle at a constant temperature $\left(23 \pm 1^{\circ} \mathrm{C}\right)$ and humidity $(60 \%)$. They had access to standard rat chow and normal water ad libitum. NaHS, acting as a $\mathrm{H}_{2} \mathrm{~S}$ donor, was dissolved in stroke-physiological saline solution (also termed 'physiological saline'; purchased from Ruji Biological Technology Development Co., Ltd., Shanghai, China) and filtered through a $0.2 \mathrm{~mm}$ device (Pall Corporation, Port Washington, NY, USA). STZ was dissolved in sodium citrate buffer ( $\mathrm{pH} 4.4$; the citric acid and trisodium citrate were purchased from Sinpharm Chemical Reagent Co., Ltd (Shanghai, China). One week later, DM was induced in SD rats by a single intraperitoneal (i.p.) $40 \mathrm{mg} / \mathrm{kg} \mathrm{STZ} \mathrm{injection}$ after an overnight fast. Instead of normal water, $5 \%$ glucose solution (Kelun Pharmaceutical Co., Ltd., Hunan, China) was administered to STZ-treated rats for $24 \mathrm{~h}$ after injection in order to prevent death caused by hypoglycemic shock. At $72 \mathrm{~h}$ following the STZ injection, blood samples were collected from the tail vein to measure blood glucose levels. Rats with fasting blood glucose levels $>16.7 \mathrm{mmol} / 1$ were considered successful DM models and were used for further investigation (59). The normal rats who did not accept the treatment of STZ were randomly divided into two groups: The control group (treated with normal saline injection every day), and the $\mathrm{H}_{2} \mathrm{~S}$-c2 group (normal rats treated with a high concentration of NaHS, c2=100 $\mu \mathrm{mol} / \mathrm{kg}$; received i.p., daily). By contrast, the rats who accepted the treatment of STZ were divided into three groups: the STZ group (diabetic rats group, treated with normal saline injection every day), the $\mathrm{STZ}+\mathrm{H}_{2} \mathrm{~S}-\mathrm{cl}$ group (diabetic rats treated with a low concentration of $\mathrm{NaHS} ; \mathrm{cl}=30$ $\mu \mathrm{mol} / \mathrm{kg}$ ) and the $\mathrm{STZ}+\mathrm{H}_{2} \mathrm{~S}-\mathrm{c} 2$ group (diabetic rats treated with a high concentration of NaHS; $\mathrm{c} 2=100 \mu \mathrm{mol} / \mathrm{kg}$ ). The rats had free to access to food and water during the experiment, and feeding conditions were consistent with the acclimatization period. Eight weeks later, rats in the five groups were weighed. Rats were anesthetized by i.p. injection of chloral hydrate $(350 \mathrm{mg} / \mathrm{kg})$. Thoracic cavities were opened, and the hearts of rats were lavaged with ice-cold normal saline, then removed and weighed. Three rats were randomly selected from the five groups, their myocardial tissues were fixed in $10 \%$ formalin for immunohistochemical examination. The remaining hearts were preserved at $-80^{\circ} \mathrm{C}$ prior to further analysis. This study including animal care was supervised and approved by the Animal Ethics Committee of the University of South China.

Body weight, heart weight/body weight $(H W / B W)$ and blood glucose assay. The body weight of the rats, and their blood glucose levels, were measured immediately prior to the STZ injection, and also subsequently, prior to their sacrifice. The following formula was used to analyze HW/BW: $\mathrm{HW} / \mathrm{BW}=$ (heart weight $/$ body weight $) \times 100$. Tail vein blood was tested for the blood glucose levels and it was analyzed during the acclimatization period, $72 \mathrm{~h}$ after STZ injection and before the end of experiment.

Histopathology and immunohistochemistry. Myocardium samples from rats were fixed using $4 \%$ paraformaldehyde (Sinopharm Chemical Reagent Co.), dehydrated with alcohol, embedded in paraffin (Sinopharm Chemical Reagent Co.) and cut into $5 \mu \mathrm{m}$ sections. Some of the samples were stained using a hematoxylin and eosin (H\&E) staining kit (Beyotime Institute of Biotechnology) and observed under a microscope (Motic BA210; Motic Medical Diagnostic Systems, Co., 
Ltd., Xiamen, China) at a magnification of $\times 200$. Several of the sections were incubated overnight with rabbit polyclonal anti-collagen I or rabbit polyclonal anti-collagen III Subsequently, after washing three times (10 min each wash) in $0.1 \mathrm{M}$ Tris buffer, the sections were flat-mounted, placed on coverslips, and images were captured using microscopy (Motic BA210; Motic Medical Diagnostic Systems, Co., Ltd.). The extent of myocyte hypertrophy was measured using $\mathrm{H} \& \mathrm{E}$-stained sections; collagen components were displayed by immunostaining (60).

SDS-PAGE and western blot analysis. Cell lysis buffer (20 mM Tris, $\mathrm{pH} 7.5 ; 150 \mathrm{mM} \mathrm{NaCl}$ and 1\% Triton $\mathrm{X}-100$ ) containing protease inhibitors (sodium pyrophosphate, $\beta$-glycerophosphate, EDTA, $\mathrm{Na}_{3} \mathrm{VO}_{4}$ and leupeptin) was added to heart tissues and homogenized on the ice. Then, lysates were centrifuged at $12,000 \mathrm{rpm}(7,992 \mathrm{~g})$ for $30 \mathrm{~min}$ at $4^{\circ} \mathrm{C}$ to attain the supernatant. Protein concentrations were quantified using a BCA protein assay kit. Protein $(15 \mu \mathrm{g})$ was used for electrophoresis using sodium dodecyl sulfate-polyacrylamide gel electrophoresis (SDS-PAGE) [the SDS-PAGE gel preparation kit (cat. no. P0012A) was purchased from Beyotime Institute of Biotechnology, and the concentration (\%) was made up according to the molecular weight of the proteins], and transferred to a polyvinylidene difluoride membrane (Merck Millipore, Billerica, MA, USA). It was then blocked in Tris-buffered saline with Tween (TBST) $(50 \mathrm{mM}$ Tris- $\mathrm{HCl}$, $\mathrm{pH} 7.5 ; 150 \mathrm{mM} \mathrm{NaCl}$; and $0.05 \%$ Tween-20) containing $5 \%$ skimmed milk for $2 \mathrm{~h}$. The primary antibodies used for western blot analysis were diluted in TBST buffer (5\% skimmed milk) at the following concentrations: The monoclonal antibodies used were: Monoclonal anti-GRP78 antibody $(1: 2,000$; cat. no. Ab108613, purchased from Epitomics, Inc., Burlingame, CA, USA), specific monoclonal mouse anti-CHOP antibody (1:1,000; cat. no. 60304-1-Ig, purchased from ProteinTech Group, Inc., Chicago, IL, USA), specific rabbit monoclonal anti-caspase-12 antibody (1:2,000, cat. no. SBP2325, purchased from Sigma-Aldrich, Inc., St. Louis, MO, USA) and mouse anti- $\beta$-actin monoclonal antibody (1:2,000; cat. no. 60008-1-Ig, purchased from ProteinTech Group, Inc.). The secondary antibodies used were as follows: Peroxidase-conjugated Affinipure goat anti-rabbit immunoglobulin $\mathrm{G}(\mathrm{IgG})(\mathrm{H}+\mathrm{L})(1: 8,000$; cat. no. SA00001-2, purchased from ProteinTech Group, Inc.) and peroxidase-conjugated Affinipure goat anti-Mouse $\operatorname{IgG}(\mathrm{H}+\mathrm{L})(1: 8,000$, cat. no. SA00001-1, purchased from ProteinTech Group, Inc.). Rabbit polyclonal anti-collagen I (1:400, cat no. BA0235) and rabbit polyclonal anti-collagen III (1:400, cat no. BA0326) were purchased from Wuhan Boster Biological Technology, Ltd. (Wuhan, China). The membranes were incubated with primary antibody overnight at $4^{\circ} \mathrm{C}$. The following day, the membranes were washed with TBST buffer three times (for $15 \mathrm{~min}$ each time), and incubated with secondary antibody for $2 \mathrm{~h}$ at normal temperature. Subsequently, the membrane was washed again. Finally, the blot was visualized using an enhanced chemiluminescence reagent kit and the optical density was quantified using the Molecular Imager VersaDoc MP 5000 system (Bio-Rad Laboratories, Inc., Hercules, CA, USA). $\beta$-actin was used to ensure that equal protein was loaded in every sample. All

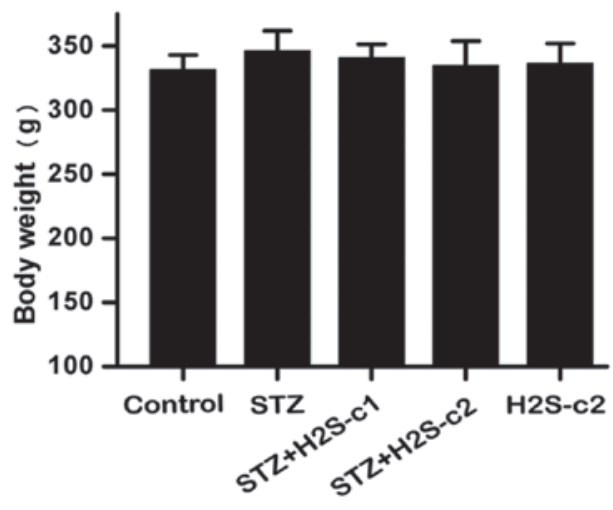

Figure 1. Body weight before streptozotocin injection.

values were normalized by setting the optical density of the control group to 1.0 .

Statistical analysis. Data are presented as the mean \pm standard error values. Potential differences between groups with different treatments were determined using one-way analysis of variance. $\mathrm{P}<0.05$ was considered to indicate a statistically significant difference. All analysis was performed using SPSS software package 18.0 (SPSS Software, Inc., Chicago, IL, USA).

\section{Results}

$\mathrm{H}_{2} \mathrm{~S}$ has no effect on $\mathrm{BW}, \mathrm{HW}, \mathrm{HW} / \mathrm{BW}$ and plasma glucose concentration. The body weight of the rats prior to the STZ injection was determined, and no significant differences among the five groups were identified (Fig. 1). The BW, HW, HW/BW and plasma glucose concentration were detected before the end of the experiment. The results revealed that the BW and $\mathrm{HW}$ in the Control group were significantly higher compared with those in the STZ group $(\mathrm{P}<0.001)$, the $\mathrm{STZ}+\mathrm{H}_{2} \mathrm{~S}-\mathrm{cl}$ group $(\mathrm{P}<0.001)$ and the STZ+H2S-c2 group $(\mathrm{P}<0.001)$. No significant differences in BW and HW were identified among the STZ, the STZ+H2S-c1 and the STZ+ $\mathrm{H}_{2} \mathrm{~S}-\mathrm{c} 2$ groups. Blood glucose levels in the STZ, STZ $+\mathrm{H}_{2} \mathrm{~S}-\mathrm{c} 1$ and $\mathrm{STZ}+\mathrm{H}_{2} \mathrm{~S}-\mathrm{c} 2$ groups were significantly higher compared with that in the Control group $(\mathrm{P}<0.001)$, although no significant differences were identified when making comparisons among the STZ, STZ $+\mathrm{H}_{2} \mathrm{~S}-\mathrm{cl}$ and STZ $+\mathrm{H}_{2} \mathrm{~S}-\mathrm{c} 2$ groups (Table I).

$\mathrm{H}_{2} \mathrm{~S}$ can reduce myocardial fibrosis caused by STZ-induced high plasma glucose concentrations. Myocardial hypertrophy was analyzed by hematoxylin and eosin staining. The results show that the myocardial tissue structure was tightly organized in the control and $\mathrm{H}_{2} \mathrm{~S}-\mathrm{c} 2$ groups, whereas it was notably looser with a less-ordered structure in the STZ group. However, these pathological changes were improved following treatment with $\mathrm{H}_{2} \mathrm{~S}$ in the STZ $+\mathrm{H}_{2} \mathrm{~S}-\mathrm{cl}$ and $\mathrm{STZ}+\mathrm{H}_{2} \mathrm{~S}-\mathrm{c} 2$ groups (Fig. 2).

$\mathrm{H}_{2} \mathrm{~S}$ can reduce myocardial fibrosis caused by high plasma glucose concentration. Myocardial collagen fibrosis was detected by immunostaining. Results showed that type I collagen (Fig. 3A) and type III collagen (Fig. 3B) expression was markedly increased, accompanied by disordered arrangement in the 
Table I. Effect of $\mathrm{H}_{2} \mathrm{~S}$ on HW, BW, HW/BW and BG.

\begin{tabular}{lccccc}
\hline Parameter & Control & STZ & STZ $+\mathrm{H}_{2} \mathrm{~S}-\mathrm{c} 1$ & $\mathrm{STZ}+\mathrm{H}_{2} \mathrm{~S}-\mathrm{c} 2$ & $\mathrm{H}_{2} \mathrm{~S}-\mathrm{c} 2$ \\
\hline BW $(\mathrm{g})$ & $437.71 \pm 64.75$ & $269.86 \pm 20.41^{\mathrm{b}}$ & $285.57 \pm 34.60^{\mathrm{b}}$ & $280.14 \pm 12.06^{\mathrm{b}}$ & $471.29 \pm 24.16$ \\
HW $(\mathrm{g})$ & $1.46 \pm 0.17$ & $1.04 \pm 0.10^{\mathrm{b}}$ & $1.08 \pm 0.13^{\mathrm{b}}$ & $1.07 \pm 0.13^{\mathrm{b}}$ & $1.52 \pm 0.96$ \\
HW/BW (x100\%) & $0.34 \pm 0.02$ & $0.39 \pm 0.04^{\mathrm{a}}$ & $0.38 \pm 0.05^{\mathrm{a}}$ & $0.38 \pm 0.05^{\mathrm{a}}$ & $0.32 \pm 0.01$ \\
BG (mmol/l) & $7.26 \pm 0.58$ & $28.5 \pm 2.55^{\mathrm{b}}$ & $24.5 \pm 6.96^{\mathrm{b}}$ & $25.2 \pm 5.54^{\mathrm{b}}$ & $8.12 \pm 2.06$
\end{tabular}

HW, heart weight; BW, body weight; BG, blood glucose. ${ }^{\mathrm{a}} \mathrm{P}<0.05$ and ${ }^{\mathrm{b}} \mathrm{P}<0.001$, compared with the control group. STZ, streptozotocin, $\mathrm{H}_{2} \mathrm{~S}$, hydrogen sulfide.
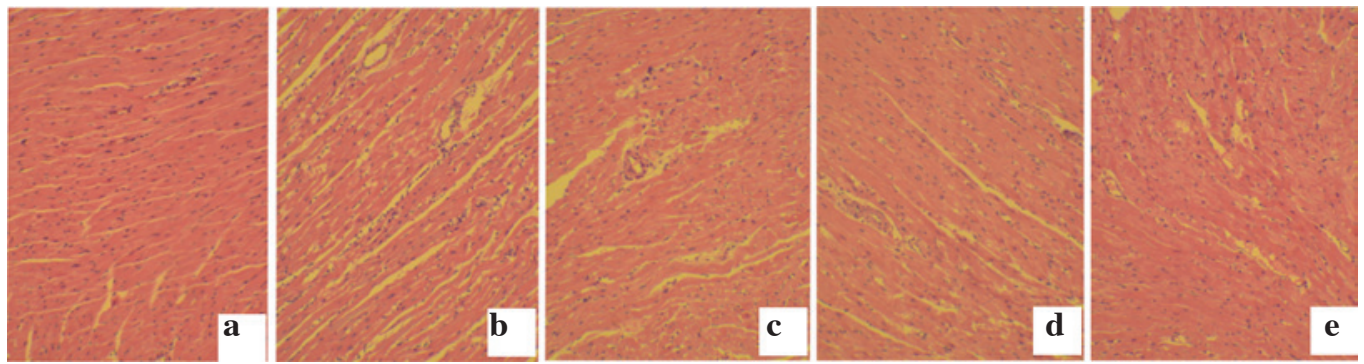

Figure 2. Effect of $\mathrm{H}_{2} \mathrm{~S}$ on the myocardial hypertrophy caused by hyperglycemia. (a) Control group; (b) STZ group; (c) STZ+ $\mathrm{H}_{2} \mathrm{~S}-\mathrm{cl}$ group; (d) $\mathrm{STZ}+\mathrm{H}_{2} \mathrm{~S}-\mathrm{c} 2$ group; and (e) $\mathrm{H}_{2} \mathrm{~S}$-c2 group. $\mathrm{H}_{2} \mathrm{~S}$, hydrogen sulfide; STZ, streptozotocin. The cells were stained with hematoxylin and eosin (x200).

A
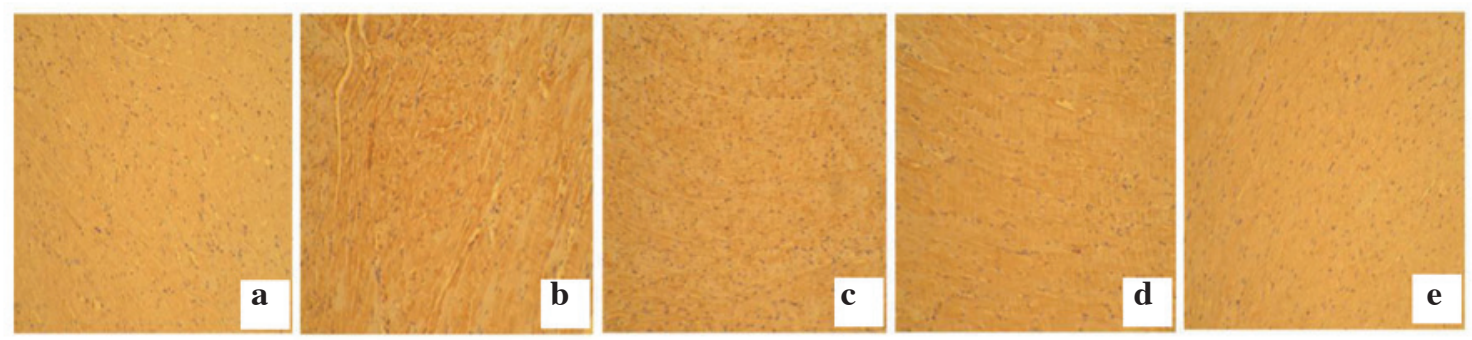

B
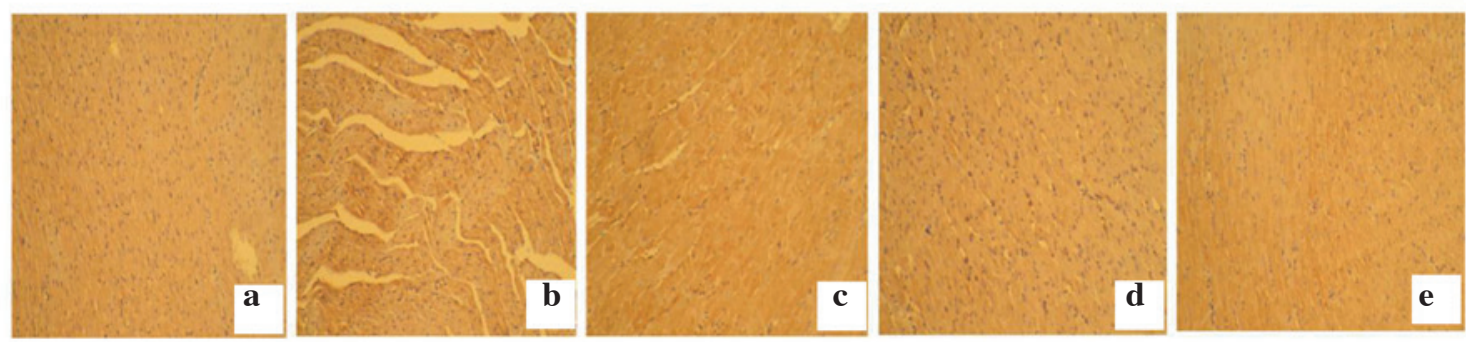

Figure 3. Effect of $\mathrm{H}_{2} \mathrm{~S}$ on the myocardial collagen fibrosis in the heart tissue of diabetes mellitus. Immunostaining of (A) collagen I and (B) collagen III after treatment of the rats with NaHS ( $30 \mu \mathrm{mol} / \mathrm{kg}$ and $100 \mu \mathrm{mol} / \mathrm{kg}$, ip) for 8 weeks (magnification, $\mathrm{x} 40$ ). (a) Control group; (b) STZ group; (c) STZ+H ${ }_{2} \mathrm{~S}-\mathrm{cl}$ group; (d) $\mathrm{STZ}+\mathrm{H}_{2} \mathrm{~S}$-c2 group; (e) $\mathrm{H}_{2} \mathrm{~S}$-c2 group. $\mathrm{H}_{2} \mathrm{~S}$, hydrogen sulfide; STZ, streptozotocin.

STZ group compared with the control group. These changes were reversed by $\mathrm{H}_{2} \mathrm{~S}$ intervention.

$\mathrm{H}_{2} \mathrm{~S}$ reduces ERS caused by high plasma glucose concentrations. High plasma glucose concentrations, caused by the injection of STZ, significantly increased the expression of caspase-12 $(\mathrm{P}<0.01)$, GRP-78 $(\mathrm{P}<0.05)$ and CHOP $(\mathrm{P}<0.05)$ proteins, which are markers of ERS. The expression of these proteins was shown to be decreased in $\mathrm{STZ}+\mathrm{H}_{2} \mathrm{~S}-\mathrm{cl}$ (caspase-12
$\mathrm{P}<0.05$, GRP-78 $\mathrm{P}<0.05, \mathrm{CHOP} \mathrm{P}<0.05)$ and $\mathrm{STZ}+\mathrm{H}_{2} \mathrm{~S}-\mathrm{c} 2$ (caspase-12 $\mathrm{P}<0.001$, GRP-78 $\mathrm{P}<0.05$, CHOP $\mathrm{P}<0.05$ ) groups, and the expression of GRP-78 and CHOP was not significant different between the control, $\mathrm{H}_{2} \mathrm{~S}-\mathrm{c} 2, \mathrm{STZ}+\mathrm{H}_{2} \mathrm{~S}-\mathrm{c} 1$ and $\mathrm{STZ}+\mathrm{H}_{2} \mathrm{~S}-\mathrm{c} 2$ groups. However, the expression of caspase-12 protein was lower in $\mathrm{STZ}+\mathrm{H}_{2} \mathrm{~S}-\mathrm{c} 2$ and $\mathrm{H}_{2} \mathrm{~S}-\mathrm{c} 2$ groups compared with the STZ $+\mathrm{H}_{2} \mathrm{~S}-\mathrm{c} 1$ group $\left(\mathrm{STZ}+\mathrm{H}_{2} \mathrm{~S}-\mathrm{c} 2 \mathrm{P}<0.05, \mathrm{H}_{2} \mathrm{~S}-\mathrm{c} 2\right.$ $\mathrm{P}<0.01)$, and was also lower in the $\mathrm{H}_{2} \mathrm{~S}-\mathrm{c} 2$ group compared with the control group $(\mathrm{P}<0.05)$. 

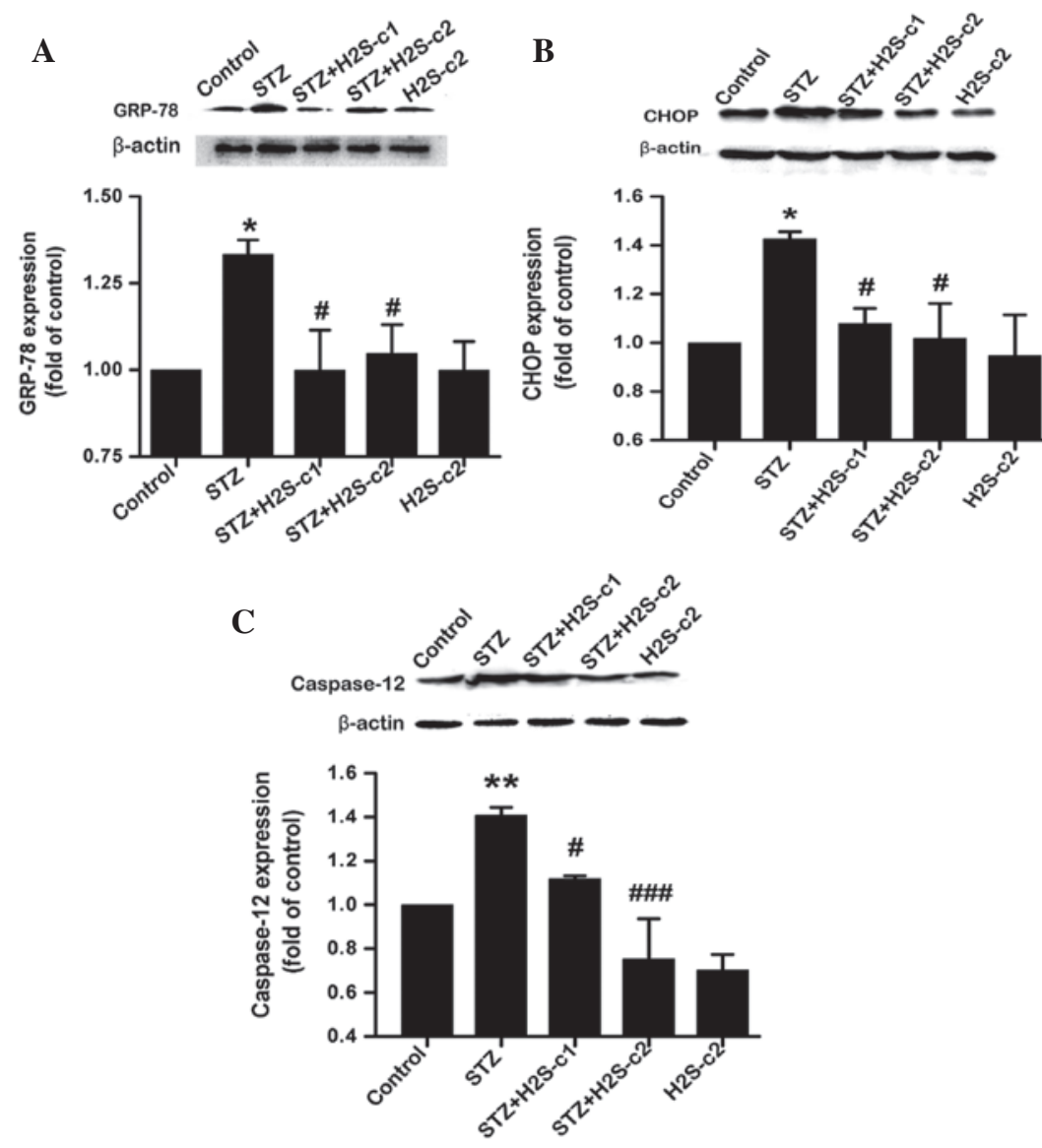

Figure 4. Effect of $\mathrm{H}_{2} \mathrm{~S}$ on the expression of Grp78, CHOP and caspase-12 in heart tissue. Western blot analysis of the protein expression of (A) Grp78, (B) CHOP and (C) caspase-12. $\beta$-actin served as a control. Bars indicate the mean \pm standard error from at least 3 independent experiments. "P<0.05 and ${ }^{* *} \mathrm{P}<0.01$ compared with the control group; ${ }^{\#} \mathrm{P}<0.05$ and ${ }^{\# \# \#} \mathrm{P}<0.001$ compared with the STZ group. $\mathrm{H}_{2} \mathrm{~S}$, hydrogen sulfide; STZ, streptozotocin; Grp78, glucose-regulated protein; CHOP, C/EBP-homologous protein.

\section{Discussion}

DM is a group of metabolic diseases characterized by hyperglycemia resulting from defects in insulin and/or insulin resistance. The long-standing hyperglycemia of DM is associated with long-term damage, dysfunction and failure of various organs, particularly the heart (61). In the current study, the DM model was established, and the histological changes were evaluated using H\&E staining to identify the existence of myocardial hypertrophy and with Masson's trichrome staining to identify the existence of myocardial fibrosis. In order to evaluate the ER stress, western blotting was used to test the expression of GRP-78, CHOP and caspase-12 protein. The present study shows that $\mathrm{H}_{2} \mathrm{~S}$ acts as a protective agent in rats with DC. The key findings were as follows: Hyperglycemia increased ERS levels, leading to myocardial hypertrophy and myocardial fibrosis in rats. Moreover, $\mathrm{H}_{2} \mathrm{~S}$ reduced the ERS caused by hyperglycemia, thus inhibiting myocardial hypertrophy and improving myocardial fibrosis.

The main pathophysiological effects of DC were myocardial fibrosis, cardiomyocyte hypertrophy and cardiac remodeling, leading to systolic and diastolic dysfunction (62). Hyperglycemia is the primary agent responsible for the occurrence and development of DC, which can lead to the progression of complex and chronic processes, including abnormal cellular metabolism and gene expression, even leading to cell death. The death of myocytes has been considered to be an important consequence of DC. As a type of permanent cell, myocytes are not capable of proliferation, and a decrease in the number of myocytes can cause systolic and diastolic dysfunction in the heart (63). The remaining cardiomyocytes embark upon a pathway of compensatory hypertrophy. Apoptosis is an important pathway for cell death, and a previous study demonstrated that myocardial apoptosis was increased notably in an STZ-induced DM model (64). Moreover, the effect of myocardial apoptosis caused by hyperglycemia was also demonstrated in vitro $(65,66)$. The pathophysiology of apoptosis was closely associated with ERS. New evidence demonstrated that hyperglycemia induced apoptosis by activating ERS $(67,68)$. In addition, in diabetic heart tissue, the ER was found to be swollen and dilated following ultrastructural analysis, suggesting abnormalities in the ER in a hyperglycemic environment (69-71). Recently, an increasing number of studies have investigated the correlation between ER stress and DC $(18,30,31) . \mathrm{H}_{2} \mathrm{~S}$ was found to be the third gaseous signaling molecule, which is involved in neuromodulation, neuroprotection, vasodilatation, cardioprotection and regulation of the inflammatory response. It is known that $\mathrm{H}_{2} \mathrm{~S}$ affects the development of DM and its complications, such as protects $\beta$-cells in the pancreas, improves insulin resistance $(56,57)$, prevents diabetic kidney from reconstruction (72) and alleviates myocardial damage in DM rat (73). It is encouraging that $\mathrm{H}_{2} \mathrm{~S}$ functions as an antioxidant, and as an 
anti-apoptotic and anti-ERS compound. It was hypothesized that $\mathrm{H}_{2} \mathrm{~S}$ could protect against DC by inhibiting ERS.

The UPR is activated following ERS to inhibit protein synthesis and promote protein folding. However, following chronic ERS, the UPR activates the apoptotic pathway (74-77). A study by Gunn et al demonstrated that activation of the UPR contributes to myocardial apoptosis (78). In addition, cytokines and norepinephrine are vital in the pathophysiology of DC and were shown to stimulate the UPR $(79,80)$. This suggests that ERS is involved in the occurrence and development of DC. Grp78, a regulatory protein of ERS, is important in assembly and folding of proteins, degradation of unfolded protein, calcium homeostasis and control of the activation of transmembrane ER stress sensors. Furthermore, Grp78 serves as a master modulator for the UPR network by binding to the ERS sensors, such as protein kinase R-like ER kinase, inositol requiring 1 (IRE1), and activating transcription factor 6 (ATF6) and inhibiting their activation (81). These results suggested that Grp78 is an activator of ER stress and UPR. Previous studies have demonstrated that two specific ER-related death pathways are involved in the apoptosis pathway. The first is activation of the transcriptional gene for CHOP and IRE1, and ATF6 signaling has been shown to be involved in the activation of ER stress $(82,83)$. A previous study demonstrated that overexpression of CHOP promotes apoptosis (84), while lack of expression of CHOP inhibits apoptosis by downregulating ER stress (85). Furthermore, CHOP lowers the expression of $\mathrm{Bcl}-2$, which is an anti-apoptosis protein (86). The second is the activation of caspase-12. It was demonstrated that pre-caspase-12 is hydrolyzed, and caspase-12 is activated during ERS (87-90). Activated caspase-12 promotes apoptosis by activating caspase- 9 and caspase- 3 through a non-cytochrome $c$-dependent pathway. The above information suggests that CHOP and caspase-12 are markers of ER stress. In the present study, expression of Grp78, CHOP and casepase-12 was increased in diabetic rats compared with controls. Conversely, $\mathrm{H}_{2} \mathrm{~S}$ decreased the expression level of these three proteins. In addition, the present study demonstrated that $\mathrm{H}_{2} \mathrm{~S}$ suppresses the expression of caspase-12 in a concentration-dependent manner, which suggests that the caspase-12-dependent apoptosis pathway is very sensitive to $\mathrm{H}_{2} \mathrm{~S}$. These findings indicated that ERS serves as an important pathophysiological mechanism for DC, and $\mathrm{H}_{2} \mathrm{~S}$ acts as a cardioprotective agent and could reduce apoptosis by inhibiting ERS in the diabetic heart.

There have been large numbers of studies reporting a decrease in BW in diabetic rats compared with normal rats (91-93). However, there is no evidence for the impact of $\mathrm{H}_{2} \mathrm{~S}$ on the $\mathrm{HW}$ and $\mathrm{BW}$ of diabetic rats. It was demonstrated that $\mathrm{H}_{2} \mathrm{~S}$ did not affect the $\mathrm{BW}$ or $\mathrm{HW}$ in diabetic rats. The potential reasons for the decrease in $\mathrm{BW}$ and $\mathrm{HW}$ are inefficient use of glucose, and increased consumption of fat and protein. A number of studies have demonstrated that as $\mathrm{H}_{2} \mathrm{~S}$ improves insulin resistance, inhibits the activity of $\alpha$-glucosidase and increases hepatic glucokinase activity and glycogen storage, it can reduce blood glucose (94-96). Conversely, the present study shows no significant effect of $\mathrm{H}_{2} \mathrm{~S}$ on blood glucose. This may be because STZ destroys the pancreatic $\beta$-cells, leading to an absolute lack of insulin secretion. Conversely, the present study reveals no significant effect of $\mathrm{H}_{2} \mathrm{~S}$ on blood glucose. Possible explanations are as follows: On one hand, STZ may destroy the pancreatic $\beta$-cells, leading to an absolute lack of insulin secretion. Although it has the effect of improving insulin resistance, $\mathrm{H}_{2} \mathrm{~S}$ has no role in reducing blood glucose. On the other hand, the animal models and experimental conditions were different.

In the clinic, most diabetic patients are suffering from DC when they go hospital, because it has gone unnoticed in terms of their health. Therefore, there is a need to focus on the effect of $\mathrm{H}_{2} \mathrm{~S}$ on cardiomyopathy in the heart. One shortcoming of the present study was that $\mathrm{H}_{2} \mathrm{~S}$ was added as an intervention factor at the same time as when the DM model was established, rather than after DC had developed. In the present study, we have confirmed the cardioprotective effects of $\mathrm{H}_{2} \mathrm{~S}$, as it restrained DC. In a subsequent study, diabetic rats will receive i.p. infusions of NaHS after the occurrence of DC, by which means we will be able to investigate clearly the therapeutic action of $\mathrm{H}_{2} \mathrm{~S}$ on DC. It is widely known that ER stress is not the only factor that impacts DC, other mechanisms, including oxidative stress, autophagy and inflammatory reactions are also involved. These mechanisms interact to stimulate the development of DC. For example, active oxygen, increased under conditions of oxidative stress, may transform gene expression and cause the abnormal functioning of signal transduction pathways; it may also activate ERS to adapt to oxidative damage. Apoptosis occurs when the damage exceeds the regulative capability of the UPR. A previous study showed that DC is associated with suppression of cardiac autophagy, and restoration of cardiac autophagy can prevent DC in DM (97). Future experiments may focus on whether $\mathrm{H}_{2} \mathrm{~S}$ exhibits a protective effect on DC by affecting oxidative stress and autophagy. In addition, other signaling pathways associated with these mechanisms are also the an area of research.

In conclusion, the present study clearly demonstrate that high blood sugar can promote the development of DC by increasing the ERS. $\mathrm{H}_{2} \mathrm{~S}$ was shown to inhibit hyperglycemia-induced ERS, resulting in myocardial protection against diabetes. This renders $\mathrm{H}_{2} \mathrm{~S}$ a potential anti-DC agent.

\section{Acknowledgements}

This study was supported by the National Natural Science Foundation of China (grant no. 81270181) and the National Natural Science Foundation of China (grant no. 81202830).

\section{References}

1. Mizushige K, Yao L, Noma T, Kiyomoto H, Yu Y, Hosomi N, Ohmori $\mathrm{K}$ and Matsuo $\mathrm{H}$ : Alteration in left ventricular diastolic filling and accumulation of myocardial collagen at insulin-resistant prediabetic stage of a type II diabetic rat model. Circulation 101: 899-907, 2000.

2. Guan SJ, Ma ZH, Wu YL, Zhang JP, Liang F, Weiss JW, Guo QY, Wang JY, Ji ES and Chu L: Long-term administration of fasudil improves cardiomyopathy in streptozotocin-induced diabetic rats. Food Chem Toxicol 50: 1874-1882, 2012.

3. Poirier P, Bogaty P, Garneau C, Marois L and Dumesnil JG: Diastolic dysfunction in normotensive men with well-controlled type 2 diabetes: Importance of maneuvers in echocardiographic screening for preclinical diabetic cardiomyopathy. Diabetes Care 24: 5-10, 2001.

4. Schannwell CM, Schneppenheim M, Perings S, Plehn G and Strauer BE: Left ventricular diastolic dysfunction as an early manifestation of diabetic cardiomyopathy. Cardiology 98: 33-39, 2002.

5. Avogaro A, Vigili de Kreutzenberg S, Negut C, Tiengo A and Scognamiglio R: Diabetic cardiomyopathy: A metabolic perspective. Am J Cardiol 93: 13A-16A, 2004. 
6. Picano E: Diabetic cardiomyopathy. The importance of being earliest. J Am Coll Cardiol 42: 454-457, 2003.

7. Abbott RD, Donahue RP, Kannel WB and Wilson PW: The impact of diabetes on survival following myocardial infarction in men vs women. The Framingham Study. JAMA 260: 3456-3460, 1988.

8. Cohen-Solal A, Beauvais F and Logeart D: Heart failure and diabetes mellitus: Epidemiology and management of an alarming association. J Card Fail 14: 615-625, 2008.

9. Trost S and LeWinter M: Diabetic Cardiomyopathy. Curr Treat Options Cardiovasc Med 3: 481-492, 2001.

10. Feuvray D: Diabetic cardiomyopathy. Arch Mal Coeur Vaiss 97: 261-265, 2004

11. Tappia PS, Asemu G, Aroutiounova N and Dhalla NS: Defective sarcolemmal phospholipase $\mathrm{C}$ signaling in diabetic cardiomyopathy. Mol Cell Biochem 261: 193-199, 2004.

12. Dyntar D, Sergeev P, Klisic J, Ambühl P, Schaub MC and Donath MY: High glucose alters cardiomyocyte contacts and inhibits myofibrillar formation. J Clin Endocrinol Metab 91: 1961-1967, 2006

13. Ligeti L, Szenczi O, Prestia CM, Szabó C, Horváth K, Marcsek ZL, van Stiphout RG, van Riel NA, Op den Buijs J, Van der Vusse GJ and Ivanics T: Altered calcium handling is an early sign of streptozotocin-induced diabetic cardiomyopathy. Int J Mol Med 17: 1035-1043, 2006.

14. Pereira L, Matthes J, Schuster I, Valdivia HH, Herzig S, Richard S and Gómez AM: Mechanisms of $[\mathrm{Ca} 2+]$ i transient decrease in cardiomyopathy of $\mathrm{db} / \mathrm{db}$ type 2 diabetic mice. Diabetes 55 : 608-615, 2006

15. Bugger H and Abel ED: Rodent models of diabetic cardiomyopathy. Dis Model Mech 2: 454-466, 2009.

16. Li Z, Zhang T, Dai H, Liu G, Wang H, Sun Y, Zhang Y and Ge Z: Involvement of endoplasmic reticulum stress in myocardial apoptosis of streptozocin-induced diabetic rats. J Clin Biochem Nutr 41: 58-67, 2007.

17. Li Z, Zhang T, Dai H, Liu G, Wang H, Sun Y, Zhang Y and Ge Z: Endoplasmic reticulum stress is involved in myocardial apoptosis of streptozocin-induced diabetic rats. J Endocrinol 196: 565-572, 2008

18. Liu ZW, Zhu HT, Chen KL, Dong X, Wei J, Qiu C and Xue JH: Protein kinase RNA-like endoplasmic reticulum kinase (PERK) signaling pathway plays a major role in reactive oxygen species (ROS)-mediated endoplasmic reticulum stress-induced apoptosis in diabetic cardiomyopathy. Cardiovasc Diabetol 12: 158, 2013.

19. Sundar Rajan S, Srinivasan V, Balasubramanyam M and Tatu U: Endoplasmic reticulum (ER) stress \& diabetes. Indian J Med Res 125: 411-424, 2007.

20. Tajiri S, Oyadomari S, Yano S, Morioka M, Gotoh T, Hamada JI, Ushio Y and Mori M: Ischemia-induced neuronal cell death is mediated by the endoplasmic reticulum stress pathway involving CHOP. Cell Death Differ 11: 403-415, 2004.

21. Dromparis P, Paulin R, Sutendra G, Qi AC, Bonnet S and Michelakis ED: Uncoupling protein 2 deficiency mimics the effects of hypoxia and endoplasmic reticulum stress on mitochondria and triggers pseudohypoxic pulmonary vascular remodeling and pulmonary hypertension. Circ Res 113: 126-136, 2013.

22. Tang C, Koulajian K, Schuiki I, Zhang L, Desai T, Ivovic A, Wang P, Robson-Doucette C, Wheeler MB, Minassian B, et al: Glucose-induced beta cell dysfunction in vivo in rats: Link between oxidative stress and endoplasmic reticulum stress Diabetologia 55: 1366-1379, 2012.

23. Back SH and Kaufman RJ: Endoplasmic reticulum stress and type 2 diabetes. Annu Rev Biochem 81: 767-793, 2012.

24. Williams JA, Hou Y, Ni HM and Ding WX: Role of intracellular calcium in proteasome inhibitor-induced endoplasmic reticulum stress, autophagy and cell death. Pharm Res 30 : 2279-2289, 2013.

25. Shinohara M, Ji C and Kaplowitz N: Differences in betaine-homocysteine methyltransferase expression, endoplasmic reticulum stress response and liver injury between alcohol-fed mice and rats. Hepatology 51: 796-805, 2010.

26. Liu G, Sun Y, Li Z, Song T, Wang H, Zhang Y and Ge Z: Apoptosis induced by endoplasmic reticulum stress involved in diabetic kidney disease. Biochem Biophys Res Commun 370 651-656, 2008

27. Marciniak SJ and Ron D: Endoplasmic reticulum stress signaling in disease. Physiol Rev 86: 1133-1149, 2006.

28. Zhao L and Ackerman SL: Endoplasmic reticulum stress in health and disease. Curr Opin Cell Biol 18: 444-452, 2006.
29. Xu K, Wang X, Shi Q, Chen C, Tian C, Li XL, Zhou RM, Chu YL and Dong XP: Human prion protein mutants with deleted and inserted octarepeats undergo different pathways to trigger cell apoptosis. J Mol Neurosci 43: 225-234, 2011.

30. Nauntofte B and Dissing $S: K+$ transport and membrane potentials in isolated rat parotid acini. Am J Physiol 255: C508-C518, 1988.

31. Lakshmanan AP, Harima M, Suzuki K, Soetikno V, Nagata M, Nakamura T, Takahashi T, Sone H, Kawachi H and Watanabe K: The hyperglycemia stimulated myocardial endoplasmic reticulum (ER) stress contributes to diabetic cardiomyopathy in the transgenic non-obese type 2 diabetic rats: A differential role of unfolded protein response (UPR) signaling proteins. Int J Biochem Cell Biol 45: 438-447, 2013.

32. Kimura H: Hydrogen sulfide as a neuromodulator. Mol Neurobiol 26: 13-19, 2002.

33. Wang R: Two's company, three's a crowd: $\mathrm{Can} \mathrm{H}_{2} \mathrm{~S}$ be the third endogenous gaseous transmitter? FASEB J 16: 1792-1798, 2002.

34. Szabó C: Hydrogen sulphide and its therapeutic potential. Nat Rev Drug Discov 6: 917-935, 2007.

35. Łowicka E and Bełtowski J: Hydrogen sulfide (H2S)-the third gas of interest for pharmacologists. Pharmacol Rep 59: 4-24, 2007.

36. Zanardo RC, Brancaleone V, Distrutti E, Fiorucci S, Cirino G and Wallace JL: Hydrogen sulfide is an endogenous modulator of leukocyte-mediated inflammation. FASEB J 20: 2118-2120, 2006.

37. Rinaldi L, Gobbi G, Pambianco M, Micheloni C, Mirandola P and Vitale M: Hydrogen sulfide prevents apoptosis of human PMN via inhibition of p38 and caspase 3. Lab Invest 86: 391-397, 2006.

38. Wang XY, Yang CT, Zheng DD, Mo LQ, Lan AP, Yang ZL, Hu F, Chen PX, Liao XX and Feng JQ: Hydrogen sulfide protects H9c2 cells against doxorubicin-induced cardiotoxicity through inhibition of endoplasmic reticulum stress. Mol Cell Biochem 363 419-426, 2012

39. Chen ZF, Zhao B, Tang XY, Li W, Zhu LL, Tang CS, Du JB and Jin HF: Hydrogen sulfide regulates vascular endoplasmic reticulum stress in apolipoprotein E knockout mice. Chin Med J (Engl) 124: 3460-3467, 2011

40. Tang XQ, Yang CT, Chen J, Yin WL, Tian SW, Hu B, Feng JQ and Li YJ: Effect of hydrogen sulphide on beta-amyloid-induced damage in PC12 cells. Clin Exp Pharmacol Physiol 35: 180-186, 2008 .

41. Hu LF, Lu M, Wu ZY, Wong PT and Bian JS: Hydrogen sulfide inhibits rotenone-induced apoptosis via preservation of mitochondrial function. Mol Pharmacol 75: 27-34, 2009.

42. Yin WL, He JQ, Hu B, Jiang ZS and Tang XQ: Hydrogen sulfide inhibits MPP (+)-induced apoptosis in PC12 cells. Life Sci 85: 269-275, 2009

43. Schreier SM, Muellner MK, Steinkellner H, Hermann M, Esterbauer H, Exner M, Gmeiner BM, Kapiotis S and Laggner H: Hydrogen sulfide scavenges the cytotoxic lipid oxidation product 4-HNE. Neurotox Res 17: 249-256, 2010.

44. Tiong CX, Lu M and Bian JS: Protective effect of hydrogen sulphide against 6-OHDA-induced cell injury in SH-SY5Y cells involves PKC/PI3 K/Akt pathway. Br J Pharmacol 161: 467-480, 2010.

45. Kida K, Yamada M, Tokuda K, Marutani E, Kakinohana M, Kaneki $\mathrm{M}$ and Ichinose F: Inhaled hydrogen sulfide prevents neurodegeneration and movement disorder in a mouse mode of Parkinson's disease. Antioxid Redox Signal 15: 343-352, 2011.

46. Chen WL, Xie B, Zhang C, Xu KL, Niu YY, Tang XQ, Zhang P, Zou W, Hu B and Tian Y: Antidepressant-like and anxiolytic-like effects of hydrogen sulfide in behavioral models of depression and anxiety. Behav Pharmacol 24: 590-597, 2013.

47. Zhao W, Zhang J, Lu Y and Wang R: The vasorelaxant effect of $\mathrm{H}(2) \mathrm{S}$ as a novel endogenous gaseous K (ATP) channel opener. EMBO J 20: 6008-6016, 2001

48. Zhao W and Wang R: H(2)S-induced vasorelaxation and underlying cellular and molecular mechanisms. Am J Physiol Heart Circ Physiol 283: H474-H480, 2002.

49. Yang G, Wu L, Jiang B, Yang W, Qi J, Cao K, Meng Q, Mustafa $\mathrm{AK}, \mathrm{Mu} \mathrm{W}$, Zhang $\mathrm{S}$, et al: $\mathrm{H}_{2} \mathrm{~S}$ as a physiologic vasorelaxant: Hypertension in mice with deletion of cystathionine gamma-lyase. Science 322: 587-590, 2008.

50. Mani S, Li H, Untereiner A, Wu L, Yang G, Austin RC, Dickhout JG, Lhoták S, Meng QH and Wang R: Decreased endogenous production of hydrogen sulfide accelerates atherosclerosis. Circulation 127: 2523-2534, 2013. 
51. Zhang $\mathrm{H}$, Guo C, Wu D, Zhang A, Gu T, Wang L and Wang C: Hydrogen sulfide inhibits the development of atherosclerosis with suppressing CX3CR1 and CX3CL1 expression. PLoS One 7: e41147, 2012

52. Wang Y, Zhao X, Jin H, Wei H, Li W, Bu D, Tang X, Ren Y, Tang $\mathrm{C}$ and Du J: Role of hydrogen sulfide in the development of atherosclerotic lesions in apolipoprotein E knockout mice. Arterioscler Thromb Vasc Biol 29: 173-179, 2009.

53. Calvert JW, Jha S, Gundewar S, Elrod JW, Ramachandran A, Pattillo CB, Kevil CG and Lefer DJ: Hydrogen sulfide mediates cardioprotection through Nrf2 signaling. Circ Res 105: 365-374, 2009.

54. Li H, Ran K, Tang ZG, Li SF and Chang YT: Effects of hydrogen sulfide preconditioning on myocardial ischemia reperfusion injury in rats. Zhejiang Da Xue Xue Bao Yi Xue Ban 41: 559-563, 2012 (In Chinese)

55. Elrod JW, Calvert JW, Morrison J, Doeller JE, Kraus DW, Tao L, Jiao X, Scalia R, Kiss L, Szabo C, et al: Hydrogen sulfide attenuates myocardial ischemia-reperfusion injury by preservation of mitochondrial function. Proc Natl Acad Sci USA 104 15560-15565, 2007.

56. Feng X, Chen Y, Zhao J, Tang C, Jiang Z and Geng B: Hydrogen sulfide from adipose tissue is a novel insulin resistance regulator. Biochem Biophys Res Commun 380: 153-159, 2009.

57. Okamoto M, Yamaoka M and Kimura T: Hydrogen sulfide and its effect on pancreatic beta-cells. Nihon Rinsho 71: 175-180, 2013 (In Japanese).

58. El-Seweidy MM, Sadik NA and Shaker OG: Role of sulfurous mineral water and sodium hydrosulfide as potent inhibitors of fibrosis in the heart of diabetic rats. Arch Biochem Biophys 506: 48-57, 2011.

59. Bhutada P, Mundhada Y, Bansod K, Bhutada C, Tawari S, Dixit P and Mundhada D: Ameliorative effect of quercetin on memory dysfunction in streptozotocin-induced diabetic rats. Neurobiol Learn Mem 94: 293-302, 2010.

60. Dong B, Yu QT, Dai HY, Gao YY, Zhou ZL, Zhang L, Jiang H, Gao F, Li SY, Zhang YH, et al: Angiotensin-converting enzyme-2 overexpression improves left ventricular remodeling and function in a rat model of diabetic cardiomyopathy. J Am Coll Cardiol 59: 739-747, 2012.

61. Schuster DP and Duvuuri V: Diabetes mellitus. Clin Podiatr Med Surg 19: 79-107, 2002.

62. Galderisi M: Diastolic dysfunction and diabetic cardiomyopathy: Evaluation by Doppler echocardiography. J Am Coll Cardiol 48 : 1548-1551, 2006

63. Adeghate E: Molecular and cellular basis of the aetiology and management of diabetic cardiomyopathy: A short review. Mol Cell Biochem 261: 187-191, 2004.

64. Cai L and Kang YJ: Cell death and diabetic cardiomyopathy. Cardiovasc Toxicol 3: 219-228, 2003.

65. Detaille D, Guigas B, Chauvin C, Batandier C, Fontaine E, Wiernsperger $\mathrm{N}$ and Leverve $\mathrm{X}$ : Metformin prevents high-glucose-induced endothelial cell death through a mitochondrial permeability transition-dependent process Diabetes 54: 2179-2187, 2005.

66. Malhotra A, Kang BP, Hashmi S and Meggs LG: PKCepsilon inhibits the hyperglycemia-induced apoptosis signal in adult rat ventricular myocytes. Mol Cell Biochem 268: 169-173, 2005.

67. Cicek FA, Toy A, Tuncay E, Can B and Turan B: Beta-blocker timolol alleviates hyperglycemia-induced cardiac damage via inhibition of endoplasmic reticulum stress. J Bioenerg Biomembr 46: 377-387, 2014

68. Cao Y, Hao Y, Li H, Liu Q, Gao F, Liu W and Duan H: Role of endoplasmic reticulum stress in apoptosis of differentiated mouse podocytes induced by high glucose. Int J Mol Med 33: 809-816, 2014

69. Bhimji S, Godin DV and McNeill JH: Myocardial ultrastructural changes in alloxan-induced diabetes in rabbits. Acta Anat (Basel) 125: 195-200, 1986

70. Jackson CV, McGrath GM, Tahiliani AG, Vadlamudi RV and McNeill JH: A functional and ultrastructural analysis of experimental diabetic rat myocardium. Manifestation of a cardiomyopathy. Diabetes 34: 876-883, 1985

71. Mulhern ML, Madson CJ, Danford A, Ikesugi K, Kador PF and Shinohara T: The unfolded protein response in lens epithelial cells from galactosemic rat lenses. Invest Ophthalmol Vis Sci 47: 3951-3959, 2006

72. Nikitina EK, Abrosimenkova NN and Rebrov LB: Changes in rat skeletal muscle actin during postmortem autolysis. Vopr Med Khim 36: 65-68, 1990 (In Russian).
73. Zhong X, Wang L, Wang Y, Dong S, Leng X, Jia J, Zhao Y, Li H, Zhang X, Xu C, et al: Exogenous hydrogen sulfide attenuates diabetic myocardial injury through cardiac mitochondrial protection. Mol Cell Biochem 371: 187-198, 2012.

74. Ma Y and Hendershot LM: The unfolding tale of the unfolded protein response. Cell 107: 827-830, 2001

75. Wiest DL, Burkhardt JK, Hester S, Hortsch M, Meyer DI and Argon Y: Membrane biogenesis during B cell differentiation: Most endoplasmic reticulum proteins are expressed coordinately. J Cell Biol 110: 1501-1511, 1990.

76. Iwakoshi NN, Lee AH, Vallabhajosyula P, Otipoby KL, Rajewsky K and Glimcher LH: Plasma cell differentiation and the unfolded protein response intersect at the transcription factor XBP-1. Nat Immunol 4: 321-329, 2003.

77. Okada K, Minamino T, Tsukamoto Y, Liao Y, Tsukamoto O, Takashima S, Hirata A, Fujita M, Nagamachi Y, Nakatani T, et al: Prolonged endoplasmic reticulum stress in hypertrophic and failing heart after aortic constriction: Possible contribution of endoplasmic reticulum stress to cardiac myocyte apoptosis. Circulation 110: 705-712, 2004

78. Gunn KE, Gifford NM, Mori K and Brewer JW: A role for the unfolded protein response in optimizing antibody secretion. Mol Immunol 41: 919-927, 2004.

79. Cardozo AK, Ortis F, Storling J, Feng YM, Rasschaert J, Tonnesen M, Van Eylen F, Mandrup-Poulsen T, Herchuelz A and Eizirik DL: Cytokines downregulate the sarcoendoplasmic reticulum pump Ca2+ ATPase $2 \mathrm{~b}$ and deplete endoplasmic reticulum $\mathrm{Ca} 2+$, leading to induction of endoplasmic reticulum stress in pancreatic beta-cells. Diabetes 54: 452-461, 2005.

80. Mao W, Iwai C, Keng PC, Vulapalli R and Liang CS Norepinephrine-induced oxidative stress causes PC-12 cell apoptosis by both endoplasmic reticulum stress and mitochondrial intrinsic pathway: Inhibition of phosphatidylinositol 3-kinase survival pathway. Am J Physiol Cell Physiol 290: C1373-C1384, 2006.

81. Schröder M and Kaufman RJ: The mammalian unfolded protein response. Annu Rev Biochem 74: 739-789, 2005.

82. Yoshida H, Okada T, Haze K, Yanagi H, Yura T, Negishi M and Mori K: ATF6 activated by proteolysis binds in the presence of NF-Y (CBF) directly to the cis-acting element responsible for the mammalian unfolded protein response. Mol Cell Biol 20: 6755-6767, 2000.

83. Wang XZ, Lawson B, Brewer JW, Zinszner H, Sanjay A, Mi LJ, Boorstein R, Kreibich G,Hendershot LM and Ron D: Signals from the stressed endoplasmic reticulum induce C/EBP-homologous protein (CHOP/GADD153). Mol Cell Biol 16: 4273-4280, 1996.

84. Zinszner H, Kuroda M, Wang X, Batchvarova N, Lightfoot RT, Remotti H, Stevens JL and Ron D: CHOP is implicated in programmed cell death in response to impaired function of the endoplasmic reticulum. Genes Dev 12: 982-995, 1998.

85. Oyadomari S, Koizumi A, Takeda K, Gotoh T, Akira S, Araki E and Mori M: Targeted disruption of the Chop gene delays endoplasmic reticulum stress-mediated diabetes. J Clin Invest 109 525-532, 2002

86. Moldoveanu E, Stoian I, Voinea L, Marta D and Popescu LM: BCL-2-general considerations. Haematologia (Budap) 29: 167-180, 1998.

87. Wang ZC, Wang JF, Li YB, Guo CX, Liu Y, Fang F and Gong SL: Involvement of endoplasmic reticulum stress in apoptosis of testicular cells induced by low-dose radiation. J Huazhong University of Science and Technology Med Sci:33: 551-558, 2013 (In Chinese).

88. Chang CF, Wang TM, Wang JH, Huang SC and Lu TW. Adolescents after Pemberton's osteotomy for developmental dysplasia of the hip displayed greater joint loading than healthy controls in affected and unaffected limbs during gait. J Orthop Res 29: 1034-1041, 2011.

89. Chen L, Ren F, Zhang H, Wen T, Piao Z, Zhou L, Zheng S, Zhang J, Chen Y, Han Y, et al: Inhibition of glycogen synthase kinase 3 beta ameliorates D-GalN/LPS-induced liver injury by reducing endoplasmic reticulum stress-triggered apoptosis. PloS One:7: e45202, 2012

90. Qiu ZL, Zhang JP and Guo XC. Endoplasmic reticulum stress and vascular endothelial cell apoptosis. Acta Academiae Medicinae Sinicae 36: 102-107, 2014 (In Chinese).

91. Fujita A, Sasaki H, Doi A, Okamoto K, Matsuno S, Furuta H, Nishi M, Nakao T, Tsuno T, Taniguchi H and Nanjo K: Ferulic acid prevents pathological and functional abnormalities of the kidney in Otsuka Long-Evans Tokushima Fatty diabetic rats. Diabetes Res Clin Pract 79: 11-17, 2008 
92. Thyagaraju BM and Muralidhara: Ferulic acid supplements abrogate oxidative impairments in liver and testis in the streptozotocin-diabetic rat. Zoolog Sci 25: 854-860, 2008.

93. Xu X, Xiao H, Zhao J and Zhao T: Cardioprotective effect of sodium ferulate in diabetic rats. Int J Med Sci 9: 291-300, 2012.

94. Ju Y, Untereiner A, Wu L and Yang $\mathrm{G} \mathrm{H}_{2} \mathrm{~S}$-induced S-sulfhydration of pyruvate carboxylase contributes to gluconeogenesis in liver cells. Biochim Biophys Acta 1850: 2293-2303, 2015.

95. Xue R, Hao DD, Sun JP, Li WW, Zhao MM, Li XH, Chen Y, Zhu JH, Ding YJ, Liu J and Zhu YC: Hydrogen sulfide treatment promotes glucose uptake by increasing insulin receptor sensitivity and ameliorates kidney lesions in type 2 diabetes. Antioxid Redox Signal 19: 5-23, 2013.
96. Hu N, Dong M and Ren J. Hydrogen sulfide alleviates cardiac contractile dysfunction in an Akt2-knockout murine model of insulin resistance: Role of mitochondrial injury and apoptosis. Am J Physiol Regul Integr Comp Physiol 306: R761-R771, 2014:

97. He C, Zhu H, Li H, Zou MH and Xie Z: Dissociation of Bcl-2-Beclin1 complex by activated AMPK enhances cardiac autophagy and protects against cardiomyocyte apoptosis in diabetes. Diabetes 62: 1270-1281, 2013. 